\title{
Spiritual Values in Biological Materials: Plants Growth and Development
}

\author{
A. Lutfauziah ${ }^{1}$, A. Handriyan ${ }^{2}$ \\ ${ }^{1}$ Doctoral Candidate of Biology Education, Universitas Negeri Malang, Indonesia \\ ${ }^{2}$ Science Education, Univeritas Trunojoyo, Indonesia \\ Email: asmaul.lutfauziah@yahoo.com
}

\begin{abstract}
Spiritual value is a value that reflects human relations with their God. The spiritual value contained in each Biology material is different. This value can be taught well when the teacher has understood the spiritual value contained in the subject being taught. The subject of "growth and development" is taught at all levels of education from junior high school to college. The purpose of this study is to examine deeply the spiritual value of Biology material, especially the subject of "plant growth and development". This research is a qualitative descriptive study. The data of this study were obtained from content analysis, namely analysis of Biology material, analysis of the Qur'anic arguments, and analysis in the perspective of Sufism. In this article, the growth and development process is limited to seed germination and fruit ripening. The results of this study include: a) someone's faith is like a seed, faith that is only on the tongue like a seed coat, but when faith is produced from personal experience in the form of a gift from Allah (haqqul yaqin and ainul yaqin) it will lead someone to the stage of ma'rifat (like oil contained in seeds). b) Plant buds can grow from parts of plants and from seeds as stated in QS. al-An'am verse 95 and 99. c) In QS. AlAn'am verse 99 also explained that humans are commanded to observe and think about the process of fruit growth and pay attention to the maturity of the fruit in order to increase their faith in Allah
\end{abstract}

Keywords: spiritual value; biology; plant growth and development; seed germination; fruit maturation

\section{INTRODUCTION}

As'ad and Harun explained that spiritual is a human relationship with his God which is reflected in his interaction as a social being. The spiritual is a human activity which leads to character, eternity, and spirit. Based on these two opinions, it can be concluded that spiritual values are values that reflect human relations with their God [1].

The spiritual value contained in each Biology material is different. For example, when the teacher teaches the digestive material. The teacher guides students to discover that God regulates the complexities and details of the digestive system. The teacher also explains the lessons or benefits of studying the digestive system so that students can live a healthy life and be more careful in choosing food. Students are taught halal and unclean food by supporting the arguments of the Qur'an and Sunnah. This is taught to students because the food consumed by students can affect the ease of students in accepting the knowledge and benefits (knowledge) that they have learned. This should be done by teachers in order to realize the goals of education in Indonesia.

Spiritual in its application is the drive for all human actions [2]. The spiritual value of Biology material can be taught well when the 
teacher has understood the spiritual value found in the subject being taught. The ultimate goal of teaching spiritual values in Biological material is that students can apply these spiritual values in their attitudes (spiritual attitudes) and daily actions.

The subject matter of "plant growth and development" is taught to students starting at junior high, high school, and university students. One example of spiritual value in the subject of plant growth and development listed in the Qur'an is that Allah sends rainwater to grow various types of plants and fruits on the earth. This is contained in the word of God QS. an-Nahl verse 11. Allah Almighty shows His power through the growth of these plants for humans who want to think about it.

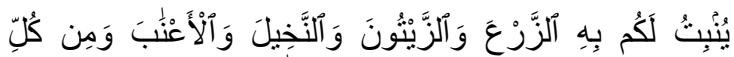

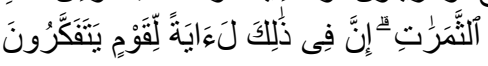

\section{Meaning:}

He grows for you with rainwater that plants; olives, palm, grapes and all kinds of fruits. Verily in this is truly a sign (the power of Allah) for those who think (QS.an-Nahl: $11)$.

The Qur'an contains various sciences such as biology, botany, zoology, entomology, chemistry, physics, economics, sociology, history, language and other disciplines. The Qur'an is the source of all sciences including biology, but most human beings are few who study and take lessons from the Qur'an in studying biology. As explained in QS. alQomar verse 22 and repeated again with the same verse recitation in QS. Al-Qomar verse 32.

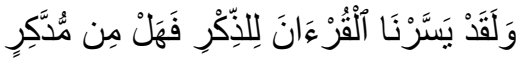

\section{Meaning:}

And in fact we have made Al Quran easy for lessons, so is there anyone who takes lessons? (Surah al-Qamar: 22, 32)

The Qur'an is the source of all science including Biology. There are verses from the Qur'an which explain botany, zoology, entomology, chemistry, physics, geography, history, economics, and other disciplines. The Qur'an is kalam and the word which contains various knowledge of Allah. The Qur'anic verse which explains the breadth of Allah's knowledge is found in QS. Al-Kahfi verse 109. The verse explains that if seawater is used as ink then 2 times the volume of seawater contained on this earth cannot write the knowledge of Allah.

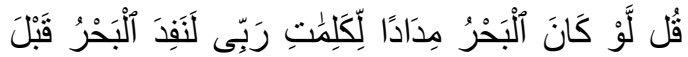

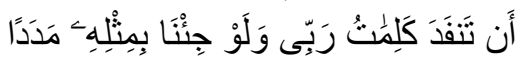

\section{Meaning:}

Say: If the sea becomes ink to (write) the sentences of my Lord, the sea is completely exhausted before the sentence of my Lord is finished, even though we bring in that much (also) "(Surat al-Kahf: 109).

Allah explained again the breadth of His knowledge as God had said in QS. Luqman verse 27.

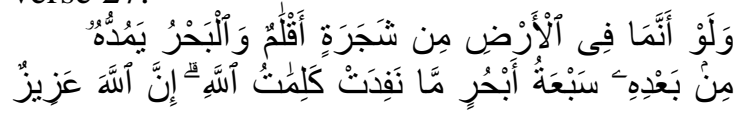
حَكِيمٌ

\section{Meaning:}

And if the trees of the earth were to become pen and sea (into ink), he added to the seven seas (again) after (dry), surely the words of Allah (His Knowledge and His Wisdom) would not be inexhaustible. Verily Allah is Mighty, Wise (Surah Luqman: 27).

The purpose of this study is to explore deeply the spiritual value contained in the material of Biology, especially the subject of plant growth and development. This result can be used as a teacher's guide in teaching spiritual values on the subject of plant growth and development in junior high, high school and college.

\section{METHOD}

This research is a qualitative descriptive study. The data of this study were obtained from content analysis, namely analysis of Biology material, analysis of the Qur'anic arguments, and analysis in the perspective of Sufism. In this study, the subject of plant growth and development is limited to the process of seed germination and fruit ripening 


\section{RESULT AND DISCUSSION}

Development is the coordination between growth and differentiation of a cell in tissues, organs, and organisms. Growth is the addition of irreversible mass due to cell division and cell enlargement. Cell differentiation is the development of cells into different forms and has special functions [3].

Growth is caused by meristematic cell activity. Meristems are cells or tissues composed of cells that have the ability to divide continuously. Cells or tissues are called meristematic if they still experience new cell formation and cell differentiation is still incomplete. Networks that have fully differentiated and become mature are called permanent. Permanent networks at certain times can change the function to meristem. There are 3 types of meristem networks namely promeristem networks, primary meristem networks, and secondary meristem networks [4].

Growth and development occur in each plant organ starting from the roots, stems, leaves, flowers, fruit to seeds. This occurs in the process of seed germination, root lengthening, stem branching, leaf yellowing, or fruit ripening. This article only discusses the spiritual value especially in seed germination and fruit ripening.

\section{A. Seed Germination}

Plant growth and development also occur during seed germination. Please note that the seeds are composed of several parts, namely the seed coat, endosperm and embryo. Seed coat as seed protectors. The endosperm serves as a food reserve for the embryo at the time of germination. Embryo as the forerunner of the plant body. When a wisdom is taken, the seeds are like someone's faith. This can be seen in Table 1.Seed germination

Secondly, the skin represents the heart and body despite the belief in the heart-protecting the body from the enemy's sword. The sword only reaches flesh which is the outer skin that makes a strip until it dies. Someone with faith like this, does not benefit from his faith. Same with faith that is only on the lips. Deep skin is useful as a guardian of seeds from damage while still stored. When the skin is used as fuel, the value is lower than the seed. This is the same as the conviction received by other majorities as having a greater advantage than just recognition on the lips. But this value is less than the confidence that results from personal experience where personal experience is a gift from God.

Table. I Seeds like someone's faith

\begin{tabular}{|c|c|c|}
\hline No. & Seed Parts & Level of Faith \\
\hline 1 & $\begin{array}{l}\text { Skin } \\
\text { Outer skin and } \\
\text { deep skin }\end{array}$ & $\begin{array}{l}\text { Skin is like a confession of } \\
\text { faith only on the tongue. } \\
\text { His belief is only limited to } \\
\text { knowledge (ilmul yaqin). }\end{array}$ \\
\hline 2 & $\begin{array}{l}\text { Seed } \\
\text { Endosperms } \\
\text { and embryos. } \\
\text { Seeds contain } \\
\text { oil. }\end{array}$ & $\begin{array}{l}\text { Beliefs generated from } \\
\text { personal practice (the grace } \\
\text { of Allah SWT) as proof of } \\
\text { his belief (ainul yaqin). } \\
\text { The oil contained in the } \\
\text { seeds is the essence, like a } \\
\text { person who believes by } \\
\text { seeing Allah (ma'rifat). }\end{array}$ \\
\hline
\end{tabular}

Third, the seeds are very noble compared to the inner skin, but the seeds are not separated from the mixture and this is still impure. Fourth, the oil taken from the seed is like a believer by seeing God through personal experience as the cause of reaching the highest level even though he is not free from other acceptance than the other than a mystic who does not consider God in His activity but $\mathrm{He}$ sees himself without others [5].

Now we turn to look at the process of seed germination! Then we take lessons from this understanding. Hopefully, the wisdom about seed germination can add to our faith.

Seeds begin to grow and develop when germinating. Seed germination depends on arbitration, namely water absorption due to the low potential of water in dry seeds. The water that has accumulated causes the seeds to expand and break the seed coat and trigger metabolic changes in the embryo. There are materials such as starch (aleurone) and cellulose which will expand when submerged in water because the material absorbs water (the absorbed molecule will be bound to the surface of the absorbing substance) [4]. Enzymes will begin to digest ingredients stored in the endosperm or cotyledons and their nutrients are transferred to the growing embryo as shown in Figure 1. 


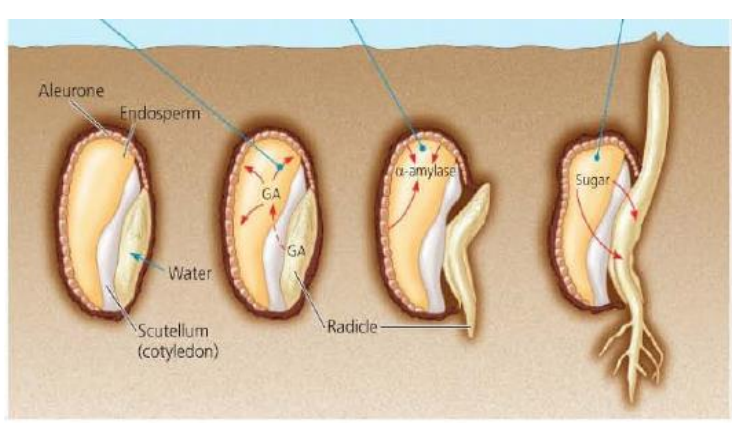

Figure 1. Mobilization of food substances during barley seed germination. After the seeds accumulate water, the embryo frees the hormone Gibberellin (GA) as a signal to the aleurone (the outer thin layer of the endosperm. Aleuron responds by synthesizing and secreting enzymes that hydrolyze food stored in the endosperm to produce small molecules that dissolve in water [6].

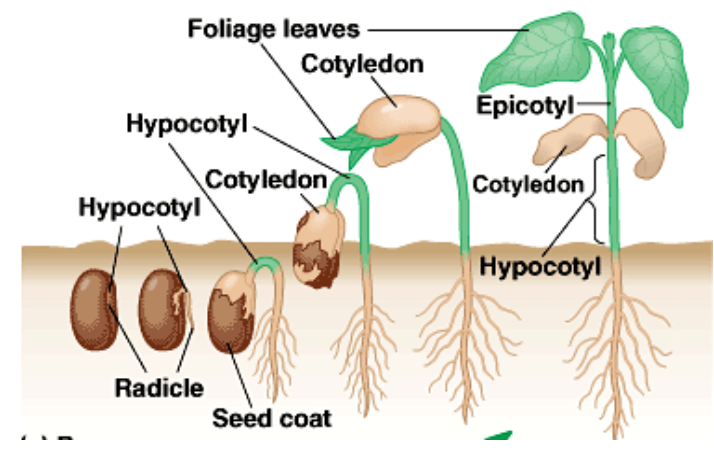

Figure 2. Seed germination. Radicules emerge from new seeds and shoots will break the surface of the soil through one of the following mechanisms: straightening a hook in the hypocotyl will attract shoots and cotyledons from the soil [6].

After the water arbitration process, the embryo will release the gibberellin hormone in high concentration. Gibberellin signals the seeds to end their dormancy and immediately germinate. Gibberellin supports embryo growth by stimulating the synthesis of hydrolytic enzymes such as a-amylase which mobilizes food stored in the endosperm to produce water-soluble molecules. Before the presence of this enzyme, gibberellins stimulated the synthesis of mRNA which encodes the synthesis of amylase enzymes. This is one example of controlling development by influencing gene expression [7].

The first organ that emerges from the germinating seed is the radicle (root), then shoots through the soil. In beans or other dicotyledonous plants, hypocotyls are shaped like hooks and growth will push the hooks up above the soil surface. Light is the main clue that tells the shoot that it has penetrated the soil. By being stimulated by light, the hypocotyl will grow straight uplifting the cotyledons and epicots as shown in Figure 2. The epicotile spreads its first leaf blade, expands and becomes green to carry out photosynthesis. Cotyledons will wither and fall out from seeds because their food reserves have been consumed by germinating embryos.

Figure 2. Seed germination. Radicules emerge from new seeds and shoots will break the surface of the soil through one of the following mechanisms: straightening a hook in the hypocotyl will attract shoots and cotyledons from the soil [6].

Plant buds can grow from various plant organs. The shoots do not only come from stem growth, but shoots can grow from tubers and leaves. This information is contained in the Qur'an (Table 2). This further strengthens our faith that the Qur'an is a source of knowledge.

Table. II The origin of apex growth

\begin{tabular}{|c|c|c|c|}
\hline No. & $\begin{array}{c}\text { Origin } \\
\text { of } \\
\text { Shoots }\end{array}$ & Example of Shoots & $\begin{array}{l}\text { Quran } \\
\text { verses }\end{array}$ \\
\hline 1 & $\begin{array}{l}\text { Plant } \\
\text { parts } \\
\text { (stem, } \\
\text { tubers, } \\
\text { leaves) }\end{array}$ & $\begin{array}{l}\text { The sugarcane shoots } \\
\text { grow from the stem } \\
\text { segments, the shoots of } \\
\text { cassava plants grow } \\
\text { from cassava tubers, the } \\
\text { buds of the cocor duck } \\
\text { plant grow from the } \\
\text { leaves }\end{array}$ & $\begin{array}{l}\text { QS. al- } \\
\text { An'am } \\
\text { verses } 95 \\
\text { and } 99\end{array}$ \\
\hline 2 & Seeds & $\begin{array}{l}\text { the shoots of corn plants } \\
\text { grow from corn seeds, } \\
\text { and the buds of citrus } \\
\text { plants grow from the } \\
\text { seeds of the citrus fruit }\end{array}$ & $\begin{array}{l}\text { QS. al- } \\
\text { An'am } \\
\text { verse } 95 .\end{array}$ \\
\hline
\end{tabular}

These two verses (Surah al-An'am verses $95 \& 99$ as in Table 2) explain the growth and development of plants. Plant growth and development begins with seed germination. Seed germination depends on arbitration, which is water absorption due to the low potential of water in the seeds because the seeds are dry. The water that has accumulated causes the seeds to expand and break the skin of the wrapping and triggers metabolic changes in the embryo. 
Plant buds can grow from parts of plants and from seeds. It is also in accordance with QS. al-An'am verse 95.

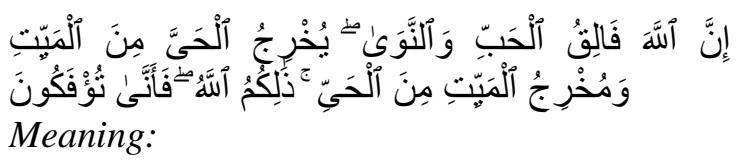

Verily Allah grows the grain of plants and fruit seeds (Surah al-An'am: 95). Tafsir Jalalain explained the verse that "Verily Allah grows the grain (shoots) of plants and fruit seeds from trees. He takes out the living from the dead like humans from semen, poultry comes from eggs, and plants come from seeds. And removing the dead are semen and eggs from the living. That is it (the one who grows and Who issues is Allah. Then why do you still turn away from faith even though the evidence is already there

Plants can grow from parts of plants and from fruit seeds. It is also in accordance with Surah al-An'am verses 95 and 99 (Table 2). The verse explains that water can grow fruit seeds and grow grains (shoots) of plants so that they become green plants.

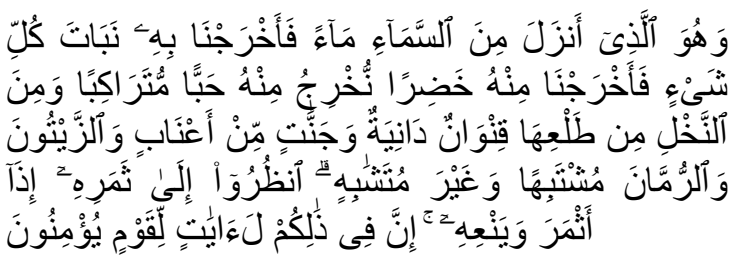

Meaning: And $\mathrm{He}$ is the one who sends down rainwater from the sky, then We grow it with all kinds of plants, so We remove from the plants' green plants (Surah Al An'am: 99).

Tafsir Jalalain explained that the verse "And He Who sends down rain from the sky, then We grow it with water, that is rain all kinds of plants that can grow, so We remove from it (from the plants) something green (which is green). We remove from the verdant plants that many grains that are one another are stacked like grain and the like. And from the date palm tree from the seed (from the date palm tree), the stems come out in the form of fruit buds that break apart from each other. And We grow the blessing of the rainwater gardens (vines, olives and pomegranates that are like leaves and not like the fruit ".

In order to grow well, plants must meet their nutritional needs, especially water needs. Plants absorb water using roots. Allah who pours the roots of a large tree so that it is embedded deep in the ground so that the roots can absorb water, salt, minerals from the soil. This is like the land as a mother who is breastfeeding her child. Soil distributes water, salt, minerals through plant roots to meet the nutritional needs of plants.

Plants that are not sufficiently deep planted will wither and die immediately, while plants rooted deep into the soil will live. Sowing the seeds in the deep soil, the plants will grow and their roots bleed in and their branches will grow. The root is like someone's faith. Happiness, glory, and peace of mind will increase when faith is increasingly rooted in the heart. Increasing faith will be directly proportional to happiness, glory, and peace of mind [8].

The soil must be cleaned from the grass before planting [5]. The grass must be removed until the roots do not just cut the grass stems because the grass can grow back if the roots are not revoked, even the grass will be more fertile. This is like a person who repents. Many people simply express regret without realizing their mistakes and have no strong determination not to commit sin anymore or even to remain drowned in the mud of sin. That is the repentance of the laity, namely external repentance which has no effect on the cause. This is like a person who wants to remove grass by cutting grass, not pulling up the roots. If someone repents and will not repeat it again, that is repentance outwardly and inwardly, then he is like pulling grass to the roots. He realized his mistake and the cause. In order for Divine love to occupy one's heart, first of all, humans must purify themselves from lust by repenting.

\section{B. Fruit maturation}

The Qur'an describes fruit ripening as in QS. al-An'am verse 99. The verse instructs people to pay attention to (attention that is accompanied by thoughts and considerations) the process of fruit growth and development that is when the tree begins to bear fruit until the fruit ripening process occurs. This is intended to increase humanity in their faith in God.

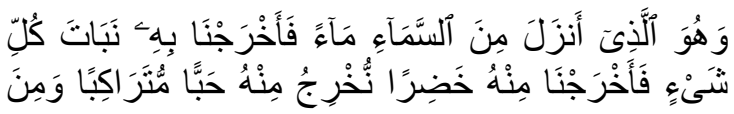




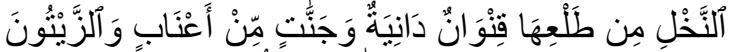

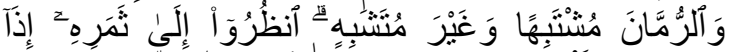

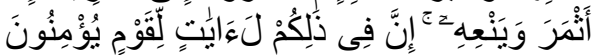

Meaning: And $\mathrm{He}$ is the one who sends down rainwater from the sky, then We grow all kinds of plants with water, so We remove from the plants green plants. We remove from the green plants that many grains; and from the date palms break down the sprouts, and the vineyards, and (We also remove) similar and unequal olives and pomegranates. Pay attention to the fruit at the time the tree is fruitful and (also pay attention) the maturity. Verily in that, there are signs (the power of Allah) for those who believe (Surah al-An'am: 99).

Tafsir Jalalain explained the verse that "And $\mathrm{He}$ Who sends down rain from the sky, then We grow it with the water which is all kinds of plants that can grow, so We remove from it (from the plant) something green (green). We remove from the verdant plants that many grains that are one another are stacked like grain and the like. And from the date palm tree from the seed (from the date palm tree), the stems come out in the form of fruit buds that break apart from each other. And We grow the blessing of the rainwater gardens (vines, olives and pomegranates that are similar in leaves and not like the fruit. Pay attention to the fruit (attention accompanied by thoughts and considerations) when the fruiting tree (at the beginning of the fruit, how is it ) and its maturity means that it is ripe when it is ripe, how it is. Truly, there is such a sign (which shows the power of Allah SWT in reviving the dead) for those who believe because only they can use it for their faith, different from infidel ".

Based on the explanation of the interpretation of QS. al-An'am verse 99 above, it was concluded that Allah had brought down rainwater to grow the seeds and shoots of plants to become a green and shady shade of fruit. Humans are instructed to observe and think about the process of fruit growth and the maturity of the fruit to increase their faith in God. Humans to believe that God is able to revive those who have died like the life of plants from seeds. Therefore, we will review the fruit maturation process from the perspective of Biology.
The phenomenon of fruit ripening can be explained by studying the hormones that play a role in fruit ripening. Auxin and cytokinine hormones play a role in increasing the size of the fruit. The fruit comes from the fruit that is in the flower. The fruit will be enlarged in size because it is triggered by the activity of hormones auxin and cytokines. When it reaches the maximum size of the fruit, at that time the fruit cells are mature and the concentration of auxin and cytokines is high. High concentration of auxin triggers the synthesis of ethylene hormone. Auxin will affect only in the concentration range around $10-8$ to $10-3 \mathrm{M}$. At higher concentrations auxin can inhibit cell elongation because high auxin can induce the synthesis of ethylene hormone [7].

Seeds that are developing will synthesize auxin to increase fruit growth After fertilization, the fruit will grow depending on the auxin produced in the seeds which develop like an experiment in Figure 5. Endosperms produce auxin during the fruiting stage and developing embryos take over auxin sources during the final stage [9].

Ethylene in the form of a gas that diffuses into a plant through the airspace between cells or dissolved ethylene can enter from one cell to another through simplas. Ethylene triggers and accelerates fruit ripening. Aging is a change in the structure and metabolism that accompanies the maturation of the ovary into fruit, which changes the cell wall which softens the fruit, decreases the chlorophyll content which causes a loss of green color.

Subhanallah, so detailed is God regulating the ripening process of fruit which is sometimes unthinkable by humans. Humans just eat only the fruit, without remembering God. He just ate without thinking of God's power. Think of the proof of His power because God has made the fruit worthy of human consumption (ripe fruit that is suitable for consumption).

In general, the fruit appears in the armpit (branch buds), but can also appear in apical buds (tip buds). Branch buds will grow into sturdy tree branches. Sturdy tree branches can support the fruit, so the fruit does not fall until cooked. 
The tree branch likens human strengths and weaknesses. The uniqueness of melons and pumpkins lying on the surface of the ground because the stalks are not strong enough to withstand heavy loads. God gives strength and strength to humans so that humans can maintain their lives to benefit other creatures. God also gives weaknesses to humans but with weaknesses that even humans can survive like melons with weak branches [8].

The gardens of hope will not pollinate the essence of life as desired [10]. The branches of patients will not bring the leaves of pleasure. The muraqabah trees will not bring forth the fruit, in the form of a position close to Us and a good place to return (QS. Shad 38: 40). The trees will not grow to perfection. That is, without recognition of human inability and without regret, humans will not get anything expected. Human patience will not produce any goodness and he will not be brought closer to God.

The human will not pick the fruit from the tree. That is to say, his eyes will always be fixed on the abundance of the world given to others and he will not be able to go beyond this mortal world to travel to the spiritual world. Therefore he will not benefit from God's promises as in QS. al-Zumar verse 34. Allah will reward many times more for sincere worshipers and approach Him. He also did not get His promise that God would grant whatever he asked.

Even more amazing things are when the fruits cook at the right time when humans need them. This shows that God knows human needs. God will fulfill human needs if indeed something is really needed by humans.

\section{CONCLUSION}

One's faith is like a seed, only faith in the tongue is like a seed coat, but when faith is produced from personal experience in the form of a gift from Allah (haqqul yaqin and ainul yaqin) it will lead someone to the ma'rifat stage (like the oil contained in seeds) Plant buds can grow from parts of plants and from seeds as stated in QS. Al-An'am verses 95 and 99. In QS. Al-An'am verse 99 also explained that humans are commanded to observe and think about the process of fruit growth and pay attention to the maturity of the fruit in order to increase their faith in Allah. Only believers can take lessons from the process of fruit maturity so that their faith will increase.

\section{REFERENCES}

[1] I. S. Tobroni. "Pendidikan Islam Paradigma Teologis, Filosofis dan Spiritualis," Malang: UMM Press., 2008,

[2] D. Hartono. "Kekuatan Spiritual paa Pemimpin Sukses," Surabaya: Media Qowiyul Amien, 2012.

[3] R. Stern, Kingsley. E. James. Bidlack \& Shelley H.Jansky. "Introductory Plant Biology (Ed. 11)," New York: McGraw Hill, 2008.

[4] H.Suwasono. "Biologi Pertanian (Tinjauan singkat tentang anatomi, fisiologi, sistematika, dan genetika dasar tumbuhtumbuhan)," Jakarta: Rajawali Press., 1987.

[5] A.Q. Jailani, "Sirrul Asrar: Hakikat Segala Rahasia Kehidupan (Terj: Zaimul Am)," Jakarta: Zaman, 2011.

[6] N. A Champbell,.; J.B. Reece; L. A. Urry; M. L. Chain; S. A. Wasserman; P. V. Minorsky \& R. B. Jackson. "Biology (Edition 8)," New York: Pearson Benjamin Cummings, 2008.

[7] N.A.Champbell; J B. Reece; L.G. Mitchel. "Biologi (Edisi 2 translted by Wasmen Manalu)," Jakarta: Erlangga, 2004.

[8] M. Smith. Al-Ghazali, "The Mystic: Study of the Life and Personality of Abu Hamid," London: Lucaz \& Company 1944.

[9] L. Taiz, \& E. Zeiger, "Plant Physiology (Third eddition)," Sunderland: Sinauer Associates, 2002.

[10] A.Q. Jailani. "Surat-Surat Cinta Kekasih Allah,” Jakarta: Zaman, 2015. 